\title{
PROTOTYPE MACHINE TO MIX AND ADDING ANIMAL FEED
}

\author{
El-Shabrawy T. H.*, Salim R. G.** and Shetewy M. A.***
}

\begin{abstract}
Small animal farms are currently adding and mixing of feed materials manually, which may cause wasting the amount of it. Transfer and delivery of the mixed animal feed to feedlots may be causes the difficulty of achieving distributed recommended ratios of feed mixing operation. Some of the interactions between the components may occur after leaving period which may cause rot and damage to the feed materials. Grinded (concentrated) animal feed is difficult to add directly in the form of powder separately. Preferably mixed them with roughage materials and adding feed materials blended automatically. To obtain the mentioned aim, locally manufactured machine achieved mixing and adding at the same time with recommended ratios obtaining a little bit losses of feed materials. To performance and evaluation of new machine, experimented in the animal farm at the three different tested factors. Four forward speeds $\left(F s_{1}=\right.$ $1.2) \&\left(F s_{2}=2.2\right) \&\left(F s_{3}=3.1\right) \&\left(F s_{4}=4.2\right) \mathrm{km} / \mathrm{h}$., Four opening hopper gate ratios (roughage feed material gate: concentrated feed material gate) $\left(G_{1}=\right.$ $1: 1) \&\left(G_{2}=1: 2\right) \&\left(G_{3}=1: 3\right) \&\left(G_{4}=1: 4\right)$ and three Revolution ratios (Mixing auger revolution: stirring shaft revolution) $(R 1=1: 1) \&(R 2=1: 2)$ $\&(R 3=1: 3)$. The animal feed adding rate as $\mathrm{kg}$ to one longitudinal meter of feedlot $(\mathrm{kg} / \mathrm{m})$, mixing quality of animal feed materials were measured. The obtained results showed that, the new machine works properly at lowest forward speed $\left(F s_{1}=1.2 \mathrm{~km} / \mathrm{h}\right)$ with deferent other treatments under study, but the optimal quantity of feed additives by machine $16 \mathrm{~kg} / \mathrm{m}$ achieved with $\left(R_{2}=1: 2\right)$, also new machine had highest efficiency of animal feed mixing process quality with all treatments under study specially with $\left(G_{3}=1: 3\right)$
\end{abstract}

\section{ITRODUCTION}

7 he supplemental fodder was designed to provide a given level of animal food in the herd, Huston (2000). Much of the variation in

response to supplement programs has been attributed for variation

* Lec. Agric. Eng. Dept., Fac. Agric. Mansoura Univ.

** Senior Researcher Agric. Eng. Res. Inst. Agric. Res. center

*** Assoc. Prof and chairman of Agric. Structures and environmental control Eng. Dept. Fac. of Agric., Al-Azhar Univ. 
in supplement intake by individual animals. Wand (2014), reported that silages, hay and grain are fed at the same time. Stationary and mobile mixers are available, new mixers use a batch-mixing approach. They require specialized feeding arrangements (drive-through feeders for mobile units, conveyor belts or wagons for stationary units). Daily time requirements include loading, mixing and dispensing, there large-batch mixers, which can grind dry hay into concentrate ratios. It is run off by PTO power and including dispensing auger. These allow bins to be filled at one or more locations. Daily time requirements include loading, mixing and dispensing. Pulsipher (2000) said that animal meals typically are combinations of dry ingredients mixed together with no further processing. Meals are a common form of range mineral supplements is difficult to bind together, and the loose form encourages consumption. Bowman and Sowell (1997) found that, 5\% of hand-fed animals failed to consume any supplement, while $19 \%$ of self-fed animals did not consume any supplement. Galyean et al. (1992) confirmed that, portable auger system may be needed to move feedstuffs to a storage destination. Feed delivery vehicles also vary in capacity and number of separate storage compartments on a single trailer. Feedstuff delivery vehicles must be able to navigate to and from on farm delivery sites easily. Narrow gates, poor road surface, and driving obstructions can limit on farm feed receiving capabilities. Comerford et al. (2013), explain the amount of beef feed vary depending on several factors whether animal breed to produce meat and animal age, large expansions in beef farms reached 50,000 head contributed to circulate feed lots and the use of horizontal and vertical feed mixers. But, Grover and Mishra (1996) mentioned the important forces that influence the compaction of biomass play their role mostly in the compression zone. The compaction occurs when the biomass is fed into a screw extruder and force is applied due to the restriction in the form of a die. Nader et al. (2000) studied the utilization of rice straw as roughage material to feed cattle. They reported that animal feeding constitutes the largest current off-field use for rice straw. Rice straw is a low-value feed, but protein content is enhanced by rapid harvest of straw to reduce volatile loss of nitrogen that occurs during extended exposure in 
the field. The farmer can vary the quality of the feed to each stall, placing high quality feed in some, and lower quality feed in others Jtaer (2007). This variation enables the high yielding cows to be given higher quality food whilst cheaper food can be given to those cows nearing the end of their lactation cycle, and producing less milk - obviously a more cost effective feeding system, while maximizing the potential for milk production. Sharma and Aggar-Wal (1987) gave a summary of the different types of machinery needed for livestock, poultry production of various types of feeds and they included grinders, feed mixers, silos elevators, automatic water pots. The aim of this study is to construct and performance evaluate a simple prototype manufactured in private workshop. To mix animal feed materials (roughage and concentrated materials) in prescribed ratios and adding it to the animals in the quantities recommended.

\section{MATERIALS AND METHODS}

Investigate the prototype has been manufactured from cheap and simple row materials taken into consideration during manufacturing process and has two options, trailed by tractor or driving with two arms by labor as needed. The experiments were conducted in the jemeza researches station in Gharbia governorate.

Important points have been taken into consideration during theoretical calculations and design the prototype such as:

- Reduce animal feed waste and scatter (as a result of the animal inflatable).

- Quality of the animal feed mixing process by machine mixing auger.

- Its preferably each meal must addition to animal in two or three stages to ensure ruminating process happens, this due to optimize nutrients of animal feed materials and drinking a lot amount of water, resulting in increased animal production of meat and milk.

\section{The manufactured prototype}

The prototype consists of multiple parts help in mixing and adding feed materials in addition to the group of transmission gears with two ground wheels and link of tractor suspension as shown in figures (1 A and B).

\section{Source of power}

A 60 HP Nasr tractor was used in the experiments, but all moving parts of prototype take its motion from ground wheel. 


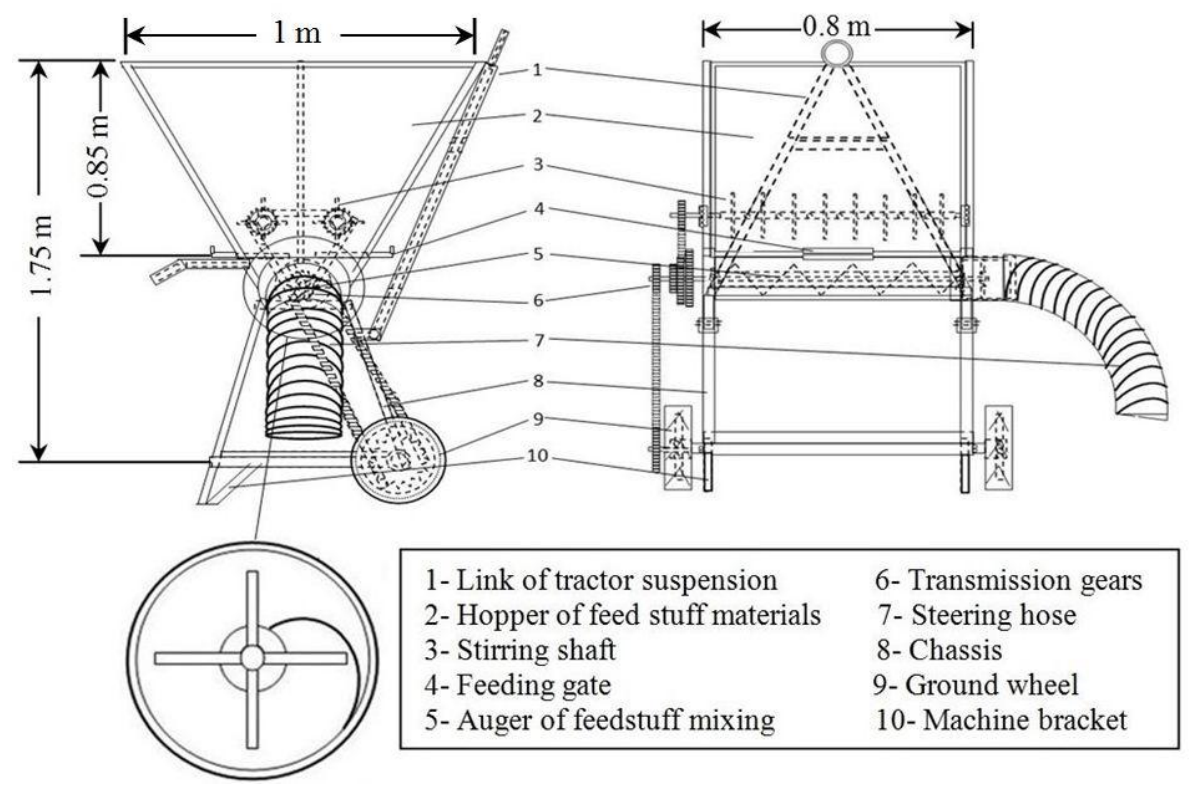

Fig. (1A): schematic diagram of parts for investigated prototype

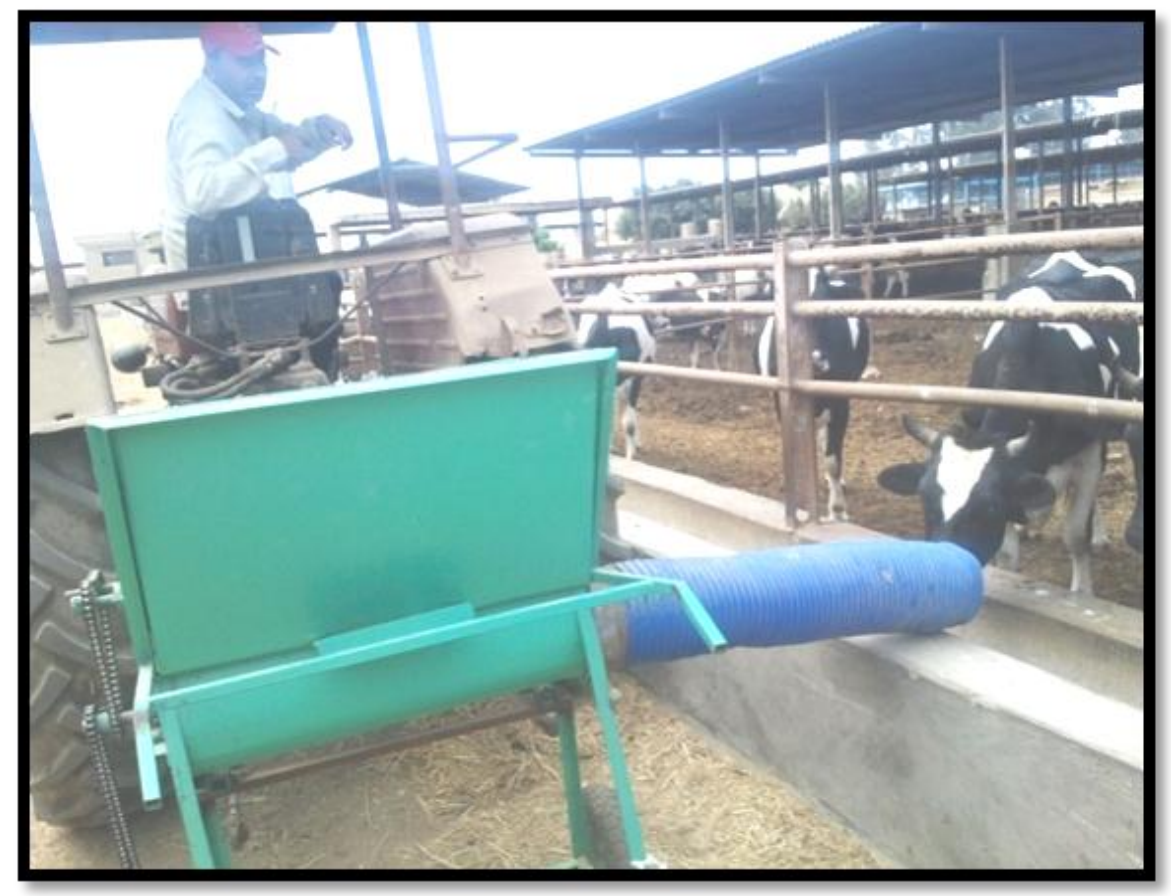

Fig. (1B): The prototype during experiments 
The prototype mechanical parts can be divided into three main groups as follow:

\section{(1) New prototype feeding parts:}

The prototype contains a hopper as shown in figure (2A) with sloping sides. It is divided into two sectors filled each one by different type of animal feed materials (roughage and concentrated materials). Each sector have feed gate and contain rotary stirring shaft as shown in figure (2B)help to flowing of feed towards feed gate then to mixing auger at the bottom of feed hopper, the control amount of feeding achieved through two sliding scaling gate at the bottom of each sector of the hopper.
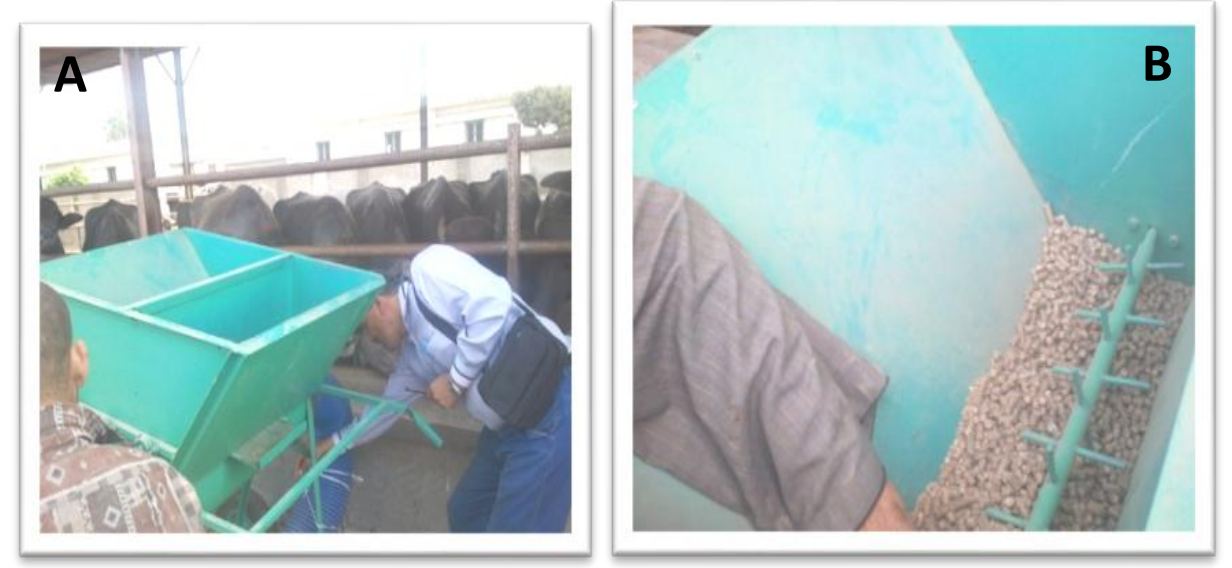

Fig. (2 A and B): Main prototype feeding parts

\section{(2) Animal feed mixing and adding mechanism}

Mixing auger was attached in the bottom of two feeding gates and hopper with geometric dimensions as shown in figure (3) based on the theory of studies, take its movement from ground wheel, with the aim to give the required amount of mixing animal feed materials per longitudinal distance. Steering hose attached auger slot to direct animal feed mixing materials into animal feedlots.

\section{(3) Prototype transmission system}

The moving parts of the prototype (stirring shaft and mixing auger) take its motion from ground wheel by groups of transmission gears with different number of teeth and chains. 


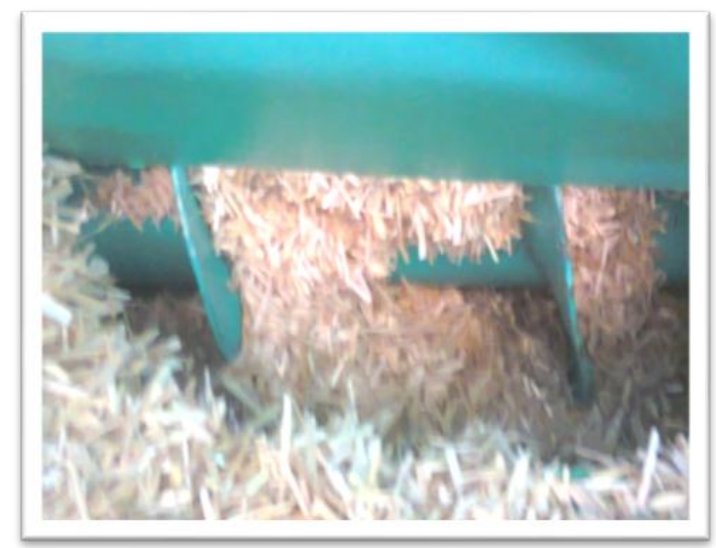

Fig. (3): Prototype mixing auger

\section{Theoretical considerations}

- One animal need $0.5 \mathrm{~m}$. of total feedlots length and the amount 8 to 8.5 $\mathrm{kg}$ of mixed feed / each meal, with density of $0.4 \mathrm{~g} / \mathrm{cm}^{3}$ as recommended by Pond and Church (1995).Then, dimensional theoretical calculations as shown in figure (4).

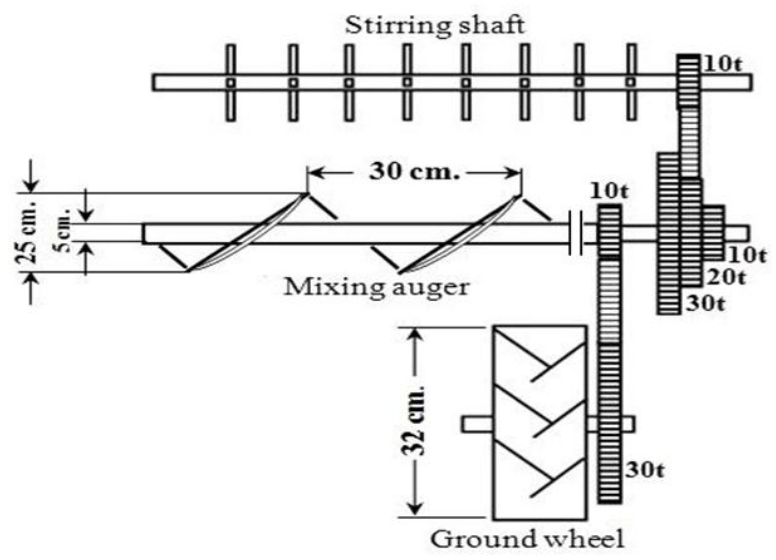

Fig. (4): A diagram illustrates the main parts dimensional of the prototype transmission system

Actual volume $\left(\mathrm{V}=\mathrm{cm}^{3}\right)$ of mixing auger step (one revolution of auger) $=$

$$
V=\tau \times G s \times\left[\left(\frac{D 1}{2}\right)^{2}-\left(\frac{D 2}{2}\right)^{2}\right]
$$


Where:

$$
\tau=3.14
$$

Gs $=$ length of auger step $c \mathrm{~m}$.

D1 = out side auger diameter $\mathrm{cm}$.

D2 = In side auger diameter cm.

$$
\therefore V=3.14 \times 30 \times\left[\left(\frac{25}{2}\right)^{2}-\left(\frac{5}{2}\right)^{2}\right]=14130 \mathrm{~cm}^{3}
$$

The amount $(\mathrm{M}=\mathrm{kg})$ of animal feed addition by one revolution of auger =

$$
\mathrm{M}=\rho \times V
$$

Where:

$$
\begin{aligned}
& \rho=\text { Density of mixed animal feed material } \frac{\mathrm{g}}{\mathrm{cm}^{3}} \\
& \therefore \mathrm{M}=0.4 \frac{\mathrm{g}}{\mathrm{cm}^{3}} \times 14130 \mathrm{~cm}^{3}=5652 \mathrm{~g}=5.6 \mathrm{~kg}
\end{aligned}
$$

Ground wheel perimeter $(\mathrm{Wp}=\mathrm{cm}$.)

$$
\mathrm{Wp}=\pi \times \mathrm{D}
$$

Where:

$$
\begin{aligned}
& \pi=3.14 \\
& \mathrm{D}=\mathrm{Ground} \text { whe } l \text { outside diameter } \mathrm{cm} . \\
& \therefore \mathrm{Wp}=3.14 \times 32=100.45 \mathrm{~cm} \approx 1 \mathrm{~m} \text { (longtudinal distance) }
\end{aligned}
$$

Mixing auger revolution: ground wheel revolution $=3: 1$

The amount of animal feed addition by one revolution of ground wheel =

$$
3 \times 5.65=16.8 \frac{\mathrm{kg}}{\mathrm{m}} \approx 16 \frac{\mathrm{kg}}{\mathrm{m}} \text { (Accord to ground wheel slippage) }
$$

\section{The studied factors as follows:}

1) Different four forward speeds $\left(\mathbf{F s}_{\mathbf{1}}=1.2\right) \&\left(\mathbf{F s}_{\mathbf{2}}=2.2\right) \&\left(\mathbf{F s}_{\mathbf{3}}=3.1\right)$ $\&\left(\mathbf{F s}_{\mathbf{4}}=4.2\right) \mathrm{km} / \mathrm{h}$.

2) Four opening gate ratios (roughage material gate: concentrated material gate) $\left(\mathbf{G}_{\mathbf{1}}=1: 1\right) \&\left(\mathbf{G}_{\mathbf{2}}=1: 2\right) \&\left(\mathbf{G}_{\mathbf{3}}=1: 3\right) \&\left(\mathbf{G}_{\mathbf{4}}=1: 4\right)$

3) Three Revolution ratios (Auger revolution: stirring shaft revolution) $(\mathbf{R} 1=1: 1) \&(\mathbf{R 2}=1: 2) \&(\mathbf{R 3}=1: 3)$

\section{Experimental measurements:}

1) Animal feed adding rate $\mathbf{k g} / \mathbf{m}$, to estimate the feed amount for meter of feedlot longitudinal distance, the plastic bags were used to collect 
feed samples from machine hose at different treatments under study according to number of machine ground wheel revelations and its external perimeter. The obtained results compared with experimental results to judge the actual performance of the machine.

2) Mixing Quality, before mixing of tested animal feed, take small sample from each type of animal feed materials $(0.5 \mathrm{~kg}$ each $)$ will mixed manually at the same experimental mixing ratios (opening gates ratios $G$ ) then estimating its volume and density (bulk density). Take experimental samples after prototype mixing process and calculated the density of each sample at different studied factors, by comparing the obtained data enable us to limit the optimum density as index to the mixing efficiency.

\section{RESULTS AND DISCUSSION}

\section{1) Animal feed adding rate $\mathrm{kg} / \mathrm{m}$}

It can be seen from figures (5A to 5C) that the forward speed had an effect on the amount of animal feed provided to feedlots. Increased in forward speed from 1.2 to $2.2 \mathrm{~km} / \mathrm{h}$ increased this amount due to increased in the vibration of the machine parts during the movement which increase the descent of animal feed quantity. By increased the forward speed from 2.2 to $4.2 \mathrm{~km} / \mathrm{h}$ we notes that decrease occurred the amount of animal feed provided by machine due to slippage occurred to machine ground wheel.

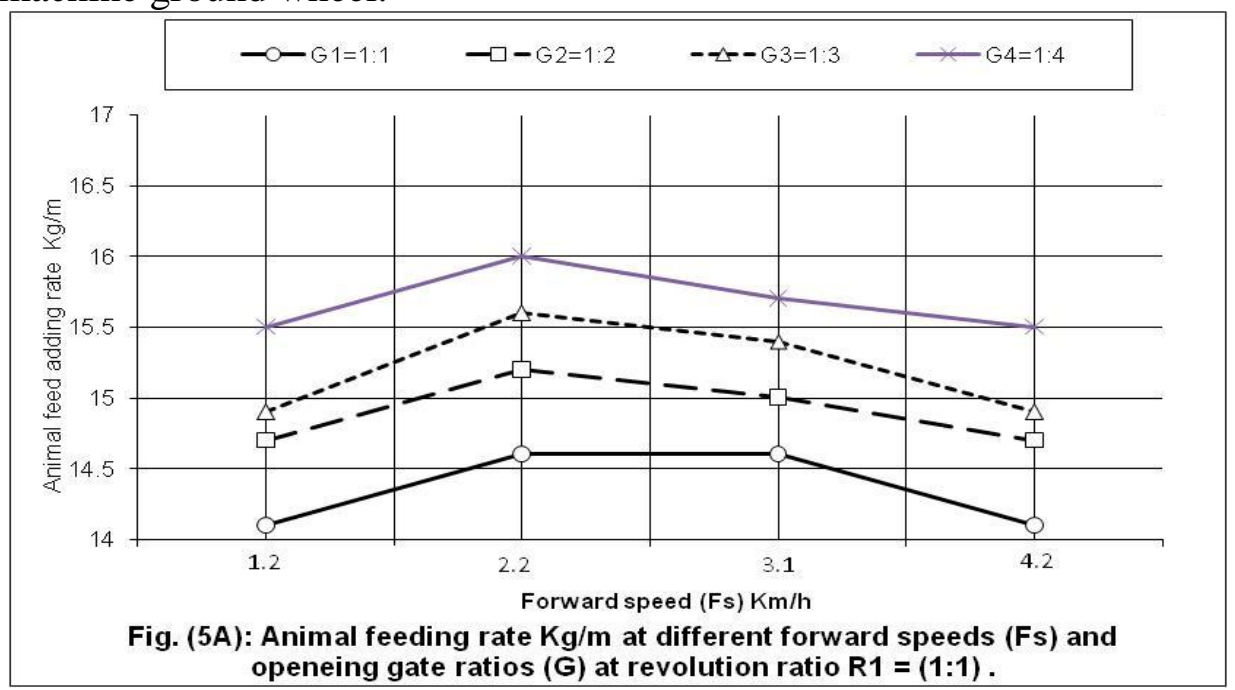




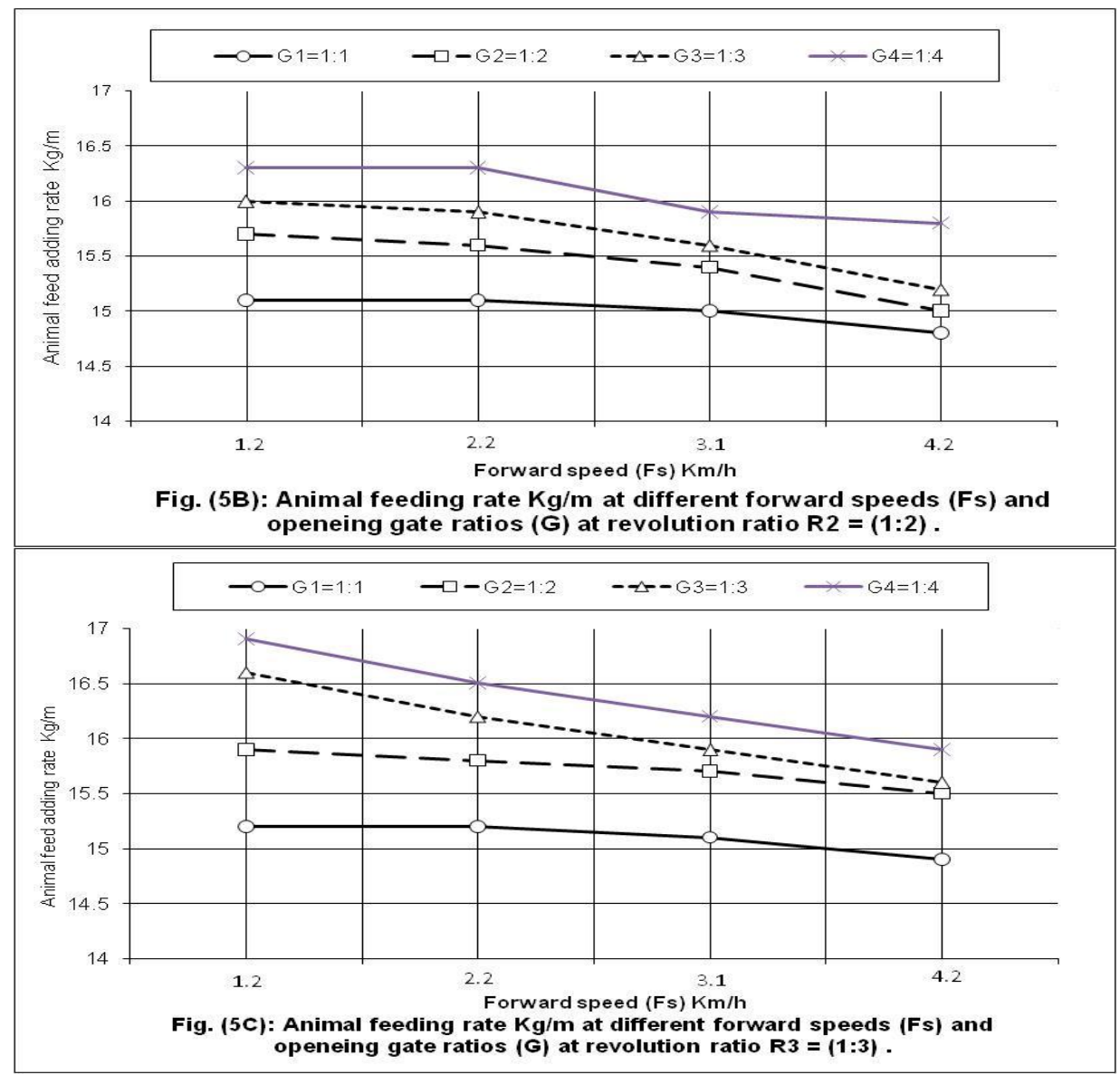

From the other side increased the value of $\mathrm{R}$ (Auger revolution: stirring shaft revolution) leads to increase the amount of animal feed adding rate $\mathrm{kg} / \mathrm{m}$, the heist value was $16.9 \mathrm{~kg} / \mathrm{m}$ occurred with $\mathrm{R} 3=1: 3$. The optimum amount of animal feed provided was $16 \mathrm{~kg}$ feed/ $1 \mathrm{~m}$ of feedlot longitudinal distance obtained at a lower forward speed Fs1 $=1.2 \mathrm{~km} / \mathrm{h}$ with $\mathrm{R} 3=1: 3$ this result conforming with theoretical consideration.

\section{2) Mixing Quality}

Referring to figures (6A to $6 \mathrm{C}$ ) one can notice that, animal feed mixed material density increased with opened feed gates ratios rate $(\mathrm{G})$ and Auger revolution:stirring shaft revolution ratios (R), this trend with different forward speeds (Fs) treatments under study, this results can be due to increased descent rate of the animal feed material which may lead to compression of feed material particles thereby increased the virtual density. 


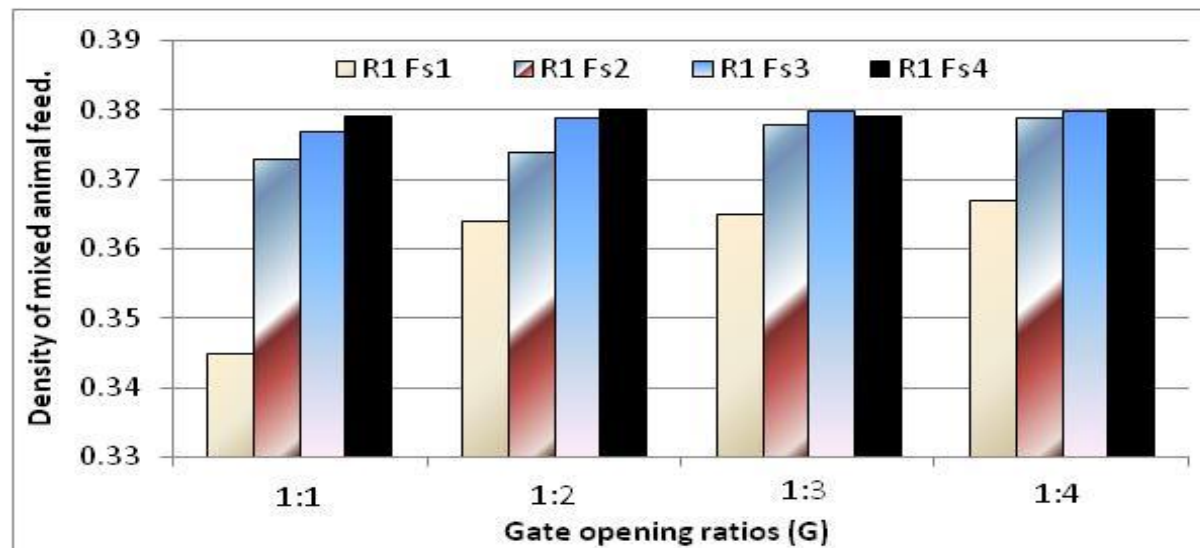

Fig. (6A): Mixing quality at different gate opening ratios (G) and forward speeds (Fs) with revolution ratio $\left(R_{1}=1: 1\right)$.
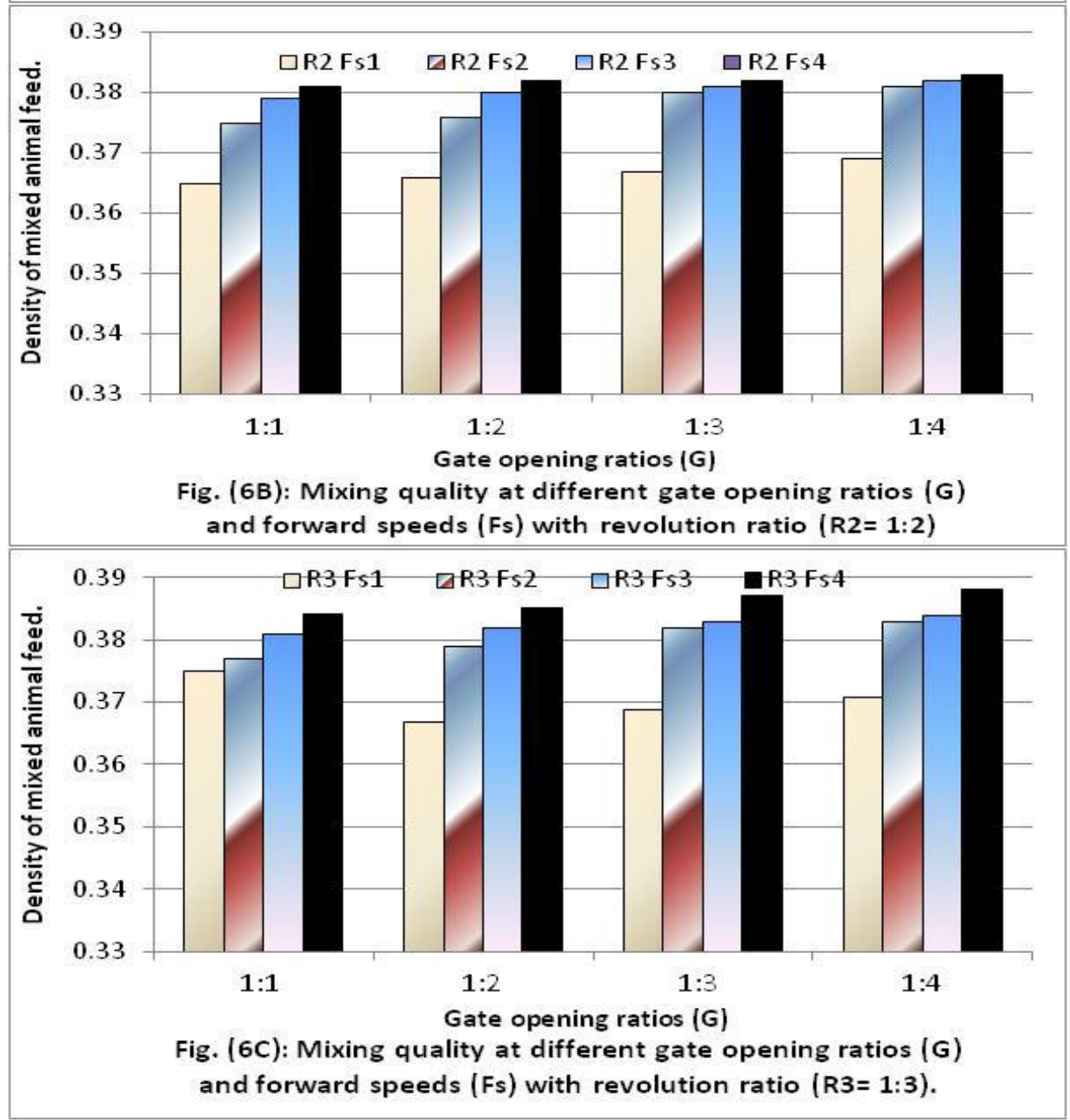

Misr J. Ag. Eng., January 2016 


\section{REFERENCES}

Bowman, J. G. P. and Sowell B. F. (1997), "Delivery method and supplement consumption by grazing ruminants." A review J. Anim. Sci. $75-543$.

Comerford, J. W.; Kime, L. F. and Harper, J. K. (2013), Agricultural Alternatives: Beef back grounding production. University Park: Penn State.

Galyean, M. L.; Macolm, K. J. and Garcia, D. R. (1992), "Effects of varying the pattern feed composition on performance by programmed fed beef steers. Clayton Livestock Res. Ctr. Prog. Rep. No. 78. N. M. Agric. Exp. Sta., Las Cruces.

Grover, P. D. and Mishra, S. K. (1996), Biomass briquetting: technology and practices. Regional wood energy development programmer in ASIA, gcp/ras/154/net. Food and agricultural organization of the united nations, Bangkok, April 1996. No. 46.

Huston, J. E. (2000), "Frequency of feeding supplements to cattle." Proc. 2000 Plains Nutrition Council Fall Grazing Conference. P.18.

Jtaer (Journal of Theoretical and Applied Electronic Commerce Research 2007). ISSN 0718-1876 Electronic Version. Vol. 2/ ISSUE 1/ April 2007/ $29-62$

Nader, G.; Mutters, R.G. and Robinson, P. (2000). Rice straw utilization by cattle. Annual report, RU-3, comprehensive research on rice, University of California and USDA, Davis. CA.

Pond, W. G. and Church, D. C. (1995), Basic animal nutrition and feeding, 1995 pp. viii + 615 pp. ISBN 0-471-30864-1. Record number 19951412223, New York, U.S.A

Pulsipher, G. D. (2000), "Supplemental nutrients for beef cows and heifers consuming low-quality forages Ph.D. dissertation, New Mexico State University, Las Cruces.

Sharma, P. C. and Aggar-Wal, D. K. (1987). Machine Design (Mechanical Engineering Design) in S.I Units S.K Kataria and Sons publishers and book Sellers, Delhi, India

Wand, C. (2014), "Nutrition and feeding systems for market lamb finishing." FACTSHEET 14-041 - AGDEX 430/61 - August 2014 


\section{الملخص العربي \\ آلة لخلط وتقديم الأعلاف الحيوانية}

د. طارق حسني الشبراوي عبد الله * ،د. رضا جمعة سالم***د. محمد أحمد شتيوى****

تعتبر الأعلاف الحيوانية وطرق خلطها وتقديمها للماثية فى المراود من أهم الأمور التى لها تأثثر

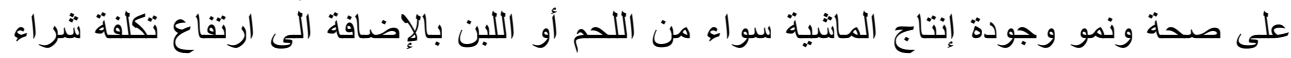

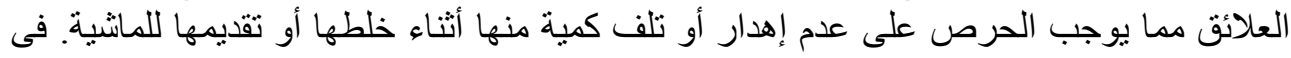

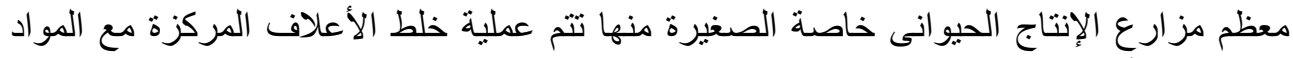

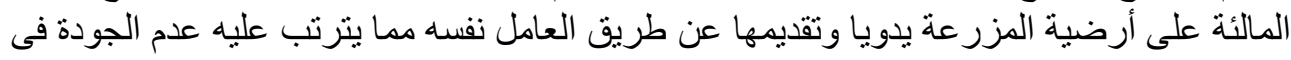

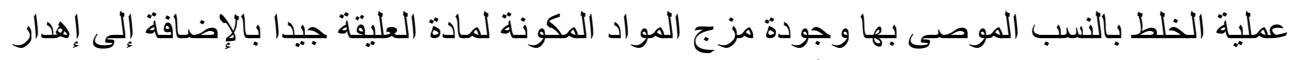

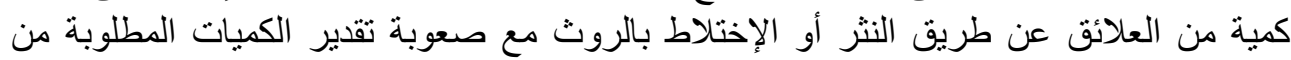
العليقة لعملية التغذية بواسطة العامل البشرى، هذا ويلاحظ أن خلط الأعلاف وتركها لفترة أو أو تخزينها عند الحاجة بترتب عليه بعض التفاعلات البيولوجية و الكيميائية التى تؤثر سلبا على الطعم

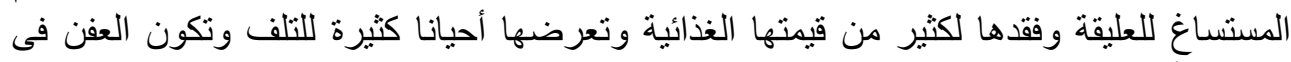

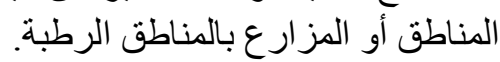

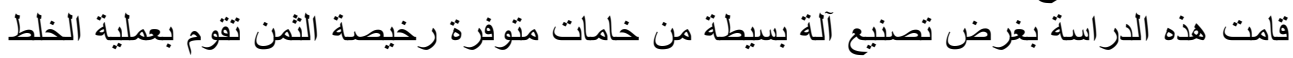

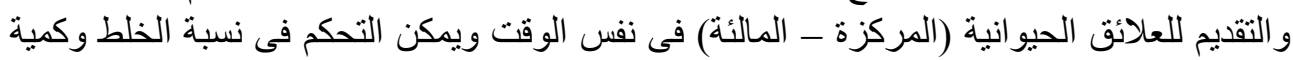

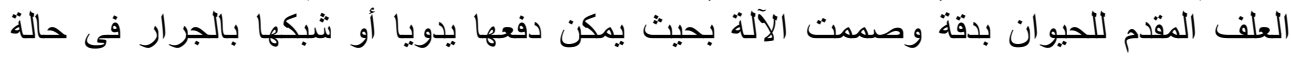

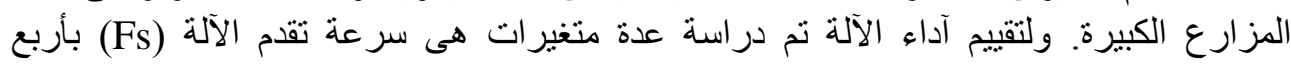

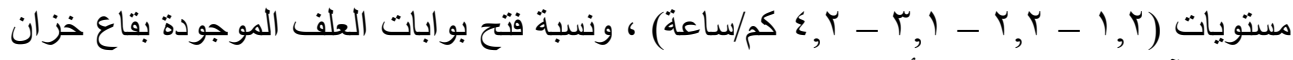

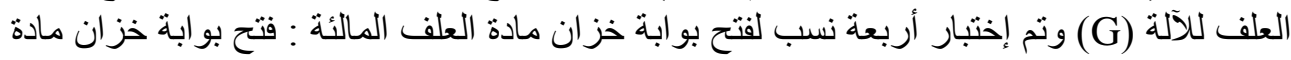

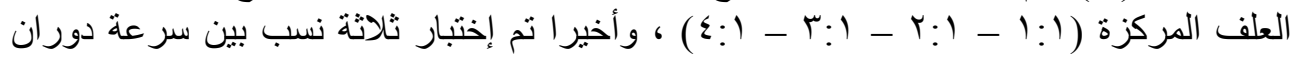
بريمة الخلط أسفل خزان العلف : سرعة دوران عامود تقليب مادة العلف داخل خزان الآلة (R) (r:1 - r:1-1:1) وتم تجريب الآلة بمزر عة محطة بحوث الجميزة - محافظة الغربية (صيف عام 0 مابـ) وتقدير كمية العلف المضافة بواسطة الآلة / المنر طولى من مرود تغذية الماثية، بالإضافة إلى كفاءة الآلة

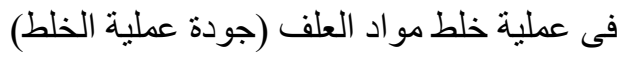

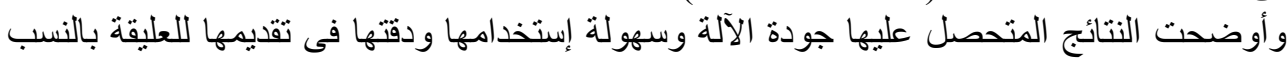

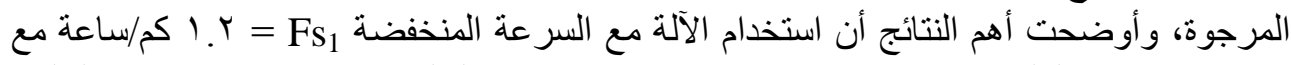

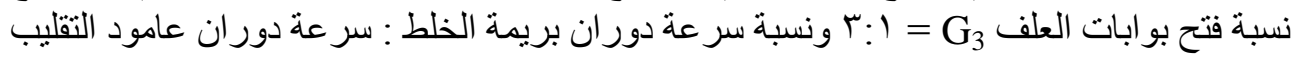

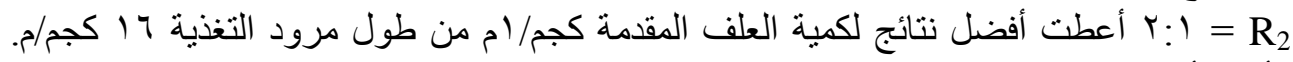

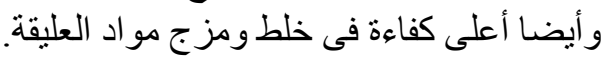

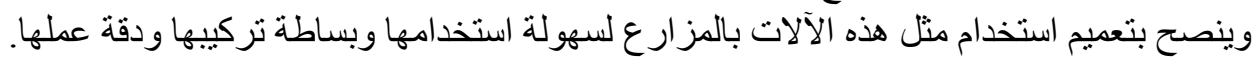

* مدرس بقسم الهندسة الزراعية ـ كلية الزراعة ـ ـ جامعة المنصورة.

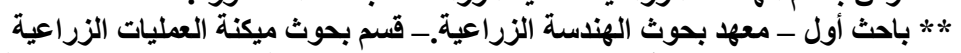

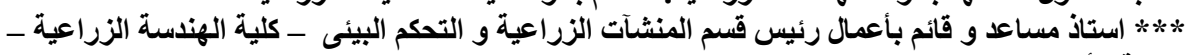
جامعة الأزهر بالقاهرة. 